Vol. 4, No. 1, Tahun 2017

\title{
PERUBAHAN BENTUK RUMAH TRADISIONAL BANUA SULU' DI MASAMBA KABUPATEN LUWU' UTARA PROPINSI SULAWESI SELATAN
}

\author{
Mithen \\ Staf Pengajar Jurusan Teknik Sipil dan Perencanaan Universitas Negeri Makassar \\ E-mail:mithen@unm.ac.id \\ Karina Puteri Rinal \\ Alumni Jurusan Teknik Sipil dan Perencanaan Universitas Negeri Makassar \\ E-mail: karina93@yahoo.co.id
}

\begin{abstract}
Abstrak
Penelitian ini bertujuan untuk melihat dan menelusuri perubahan bentuk rumah tradisional Banua Sulu' di Masamba Kabupaten Luwu' Utara. Jenis penelitian adalah penelitian kualitatif. Pengumpulan data dilakukan dengan observasi, wawancara, dan dokumentasi eksploratif untuk mencari dokumen-dokumen masa lampau dan menelusuri perubahan bentuk Banua Sulu' Variabel penelitian, terdiri atas: Tata letak, tata ruang, Fasade, Struktur/material struktur, dan ornamen. Teknik analisis data yang digunakan adalah analisis deskriftif kualitatif, yaitu menganalisis setiap variabel secara deskriptif, memaknai setiap perubahan yang terjadi, yang terdiri atas empat alur kegiatan, yaitu pemilihan data, penyajian data, analisis dan penarikan kesimpulan. Hasil penelitian menunjukkan bahwa telah terjadi perubahan bentuk secara signifikan terutama dalam hal penggunaan material struktur. Hal ini digunakan ketika adanya renovasi, dan elemen wujud fisik yang paling banyak berubah adalah bagian Atap (Botting langi) terutama coppo' atau timpa' laja' yang awalnya bersusun dua, telah berubah menjadi bersusun tiga, material atap juga berubah dari atap daun rumbia menjadi atap seng. Pada bagian badan rumah ( Ale bola) utamanya lantai dan dinding hampir keseluruhan diganti yang mengakibatkan hilangnya identitas pada bentuk ornamen dinding, jumlah tiang juga bertambah dari 36 menjadi 43 buah, serta adanya penambahan ruang yang disebabkan oleh kebutuhan ruang untuk mewadahi aktivitas penghuni, yang telah berubah menjadi masyarakat modern.
\end{abstract}

Kata-kata kunci: perubahan, bentuk, rumah tradisional, Banua Sulu’

\section{THE TRANSFORMATION OF TRADITIONAL HOUSE OF BANUA SULU' IN MASAMBA LUWU' UTARA REGENCY SOUTH SULAWESI PROVINCE}

\begin{abstract}
This study aimed to see and track changes in the traditional house form of Banua Sulu' in North Masamba Luwu' Regency. This type of research is qualitative research. Data was collected by observation, interview, and exploratory documentation search for past documents and do track changes of Banua Sulu' shape. Variables of research consist of zone layout, spatial layout, facade, structure/material of structures, and ornaments. The data analysis technique used was descriptive qualitative analysis, which analyzed every variable descriptive and interpret the meaning of any changes that occurred, four-flow of activities, namely the selection of data, presentation of data, analysis, and conclusion. The results showed that there has been a significant change in shape, especially in terms of the use of structural materials. It is used when they did renovation and the
\end{abstract}


most changing physical form elements was the roof (Botting langi) mainly coppo' or overwrite timpa' laja', which was originally duplex, has turned into a three-tiered, roof material was also changed from the roof of sago palm leaves into tin roof. In the main shape of the house (Ale bola), main floor and walls were almost entirely replaced, resulting in a loss of identity in the form of wall ornaments, the number of poles also increased from 36 to 43 pieces, and the additional rooms caused by the need for space to accommodate the occupants, who has transformed into a modern society.

Keywords: transformation, forms, traditional house, Banua Sulu'

\section{Pendahuluan}

Banua Sulu' adalah rumah tradisional bangsawan Luwu' yang mempunyai peranan penting pada masa lampau, di mana jenis (tipe) rumah tradisional seperti ini dihuni oleh para bangsawan dan penguasa adat yang memerintah dan menjalankan aturan-aturan adat untuk mengatur tata kehidupan masyarakat tradisional pada masa lampau. Tipe rumah tradisional seperti ini, mempunyai perbedaan bentuk dengan rumah masyarakat pada umumnya, terutama dari segi ukuran yang lebih besar serta ornamen-ornamen tertentu yang tidak terdapat pada rumah masyarakat umum. Tipe rumah tradisional seperti ini, di samping jumlahnya memang hanya sedikit, juga telah mengalami perubahan bentuk akibat pengaruh teknologi bahan bangunan, serta semakin sulitnya bahan-bahan lokal sebagai material struktur pengganti. Walaupun sebenarnya rumah tradisional seperti ini merupakan aset budaya bangsa yang perlu dilestarikan, sebagai salah satu kearifan lokal masyarakat dan warisan masa lampau yang dapat memperkaya seni budaya di tanah air, khususnya seni arsitektur tradisional. Persoalannya adalah banyak orang yang tidak peduli lagi terhadap nilai-nilai kearifan lokal tersebut, di samping adanya pengaruh teknologi dan perubahan peradaban sehingga rumah-rumah tradisional yang masih ada juga mengalami perubahan, baik dari segi fungsi maupun tampilan arsitektural. Oleh sebab itu, pada penelitian ini Peneliti ingin melihat adakah perubahan bentuk yang terjadi pada rumah tradisional Banua Sulu? Dengan pertanyaan penelitian ini, sehingga tujuan yang ingin dicapai adalah ingin mengetahui perubahan bentuk yang terjadi pada rumah tradisional Banua Sulu.

Sasarannya adalah melihat sejauh mana perubahan itu dibandingkan dengan bentuk awal yang dapat dideteksi berdasarkan dokumen-dokumen yang dapat dikumpulkan sebagai bahan perbandingan dan sebagai alat evaluasi untuk melihat perubahan bentuk itu sendiri. Untuk melihat perubahan tersebut, akan dianalisis berdasarkan variabel penelitian yang ditetapkan, yaitu: Variabel tata letak menyangkut orientasi bangunan terhadap jalan, variabel tata ruang menyangkut jenis ruang dan fungsi ruang yang ada, variabel fasade menyangkut penampilan bangunan baik dari sisi depan dan dari sisi samping, variabel material struktur menyangkut penggunaan bahan bangunan yang digunakan baik pada masa lampau maupun yang digunakan sekarang, dan variabel ragam hias menyangkut hiasan-hiasan yang bermakna simbolik dan segala perubahannya.

Rumah tradisioanl adalah produk arsitektur masa lampau sehingga rumah tradisional sering juga diartikan sebagai arsitektur tradisional. Menurut pendapat beberapa ahli, pengertian arsitektur adalah hasil dari proses perancangan dan pembangunan seseorang/ sekelompok orang dalam rangka memenuhi kebutuhan ruang untuk melaksanakan kegiatan tertentu. (Lullulangi, 2007 :2). Arsitektur dapat juga berarti seni bangunan, ilmu yang mempelajari tentang bangunan atau lebih lanjut Mangunwijaya (1992) mengatakan: Istilah arsitektur dalam bahasa Jawa Kuno adalah Wastuwidya (vastu-wastu $=$ bangunan, vidia-widya $=$ ilmu). Pengertian ini lebih luas dan menyeluruh jika dibandingkan dengan kata Yunani Architectonicas (seni bangunan) yang berarti pembangunan utama atau ahli pembangunan.

Pendapat lain, dikemukakan oleh Ruskin (1849), mengatakan: Architecture mirrors the various aspects of our lifes, social, economic, and spiritual". Arsitektur mencerminkan berbagai 
aspek kehidupan: masyarakat, ekonomi, dan spiritual. Arsitektur merupakan ungkapan pola masyarakatnya (Architecture is statement of society's pattern). Kemudian Le Corbusier (1923) mengatakan bahwa: "Architecture is the masterly, correct and magnificent play of masses brought together in light". Arsitektur adalah permainan massa bangunan yang mengagumkan, benar dan berharga dari massa-massa bangunan yang dibawa untuk dipadukan dalam cahaya. (Altman 1985). Jika pengertian arsitektur dihubungkan dengan pengertian tradisi, maka arsitektur tradisional adalah perancangan dan pembangunan yang dilakukan dengan cara yang sama sejak beberapa generasi tanpa perubahan yang berarti, dalam rangka memenuhi kebutuhan ruang untuk melaksanakan kegiatan tertentu pada masa lampau.. (Lullulangi, 2007 :10).

Berbicara tentang rumah tradisional secara spesifik, ada beberapa pendapat ahli yang mengemukakan definsi, antara lain: Robinson (1983) memberikan pengertian bahwa " Rumah tradisional yaitu rumah panggung kayu mewakili sebuah tradisi yang bertahan lama. Bentuk dasar rumah adalah sebuah kerangka kayu dimana tiang menahan lantai dan atap dari berbagai bahan". Rumah tradisional memiliki pengertian sebagai suatu bangunan yang mempunyai struktur, cara pembuatan, bentuk, fungsi, dan ragam hiasnya memilki ciri khas tersendiri, yang diwariskan secara turun - temurun, serta dapat dipakai oleh penduduk daerah setempat untuk melakukan aktivitas kehidupan dengan sebaik-baiknya (Said, 2004: 47).

Istilah lain untuk membedakan rumah tradisonal dengan rumah biasa, adalah rumah adat atau rumah asli atau rumah rakyat (Said, 2004: 48). Kriteria dalam menilai keaslian rumahrumah tradisional antara lain kebiasaan-kebiasaan yang menjadi suatu peraturan yang tidak tertulis saat rumah didirikan ataupun mulai digunakan. Ada ritual-ritual tertentu misalnya upacara mendirikan tiang pertama, selamatan, penentuan waktu yang tepat. Selain hal tersebut, masih banyak tata cara atau aturan yang dipakai, misalnya arah rumah, bentuk, warna, motif hiasan, dan bahan bangunan yang digunakan, sesajen, doa atau mantera yang harus dibaca dan sebagainya sangat erat kaitannya dengan rumah tradisional. (Machmud, $2006: 180$ ).

Pengertian bentuk adalah Rupa atau wujud yang ditampilkan (Depdikbud, 2007). Secara umum bentuk rumah tradisional memiliki kesamaan yang khas. Landasan (fondasi) rumah panggung berupa sepotong batu atau umpak yang berada di permukaan tanah. Di atasnya berdiri struktur rangka kayu dengan 2 sistem. Pertama konstruksi bertiang banyak dengan balok-balok pengikat. Sistem hubungan tiang balok menggunakan pasak dan pen. Yang kedua konstruksi balok bulat tersusun horizontal sebagai penyangga badan rumah (Soeroto,2003:35-36).

Runa (1993) Mengungkapkan perubahan yang terjadi pada tata fisik rumah disebabkan oleh perubahan pola pikir manusia. Perubahan tersebut berupa perubahan kecil, sedang, besar. Perubahan ini terkait dengan keadaan status sosial pemiliknya (kelompok elit, terdidik, kaya dan hamba). Bangunan kompleks dan terkait dengan ritus desa lebih sulit berubah dibanding dengan ritus individu keluarga. Perubahan dapat ditelusuri melalui fasilitas sosial dan ekonomi, aturan penataan pekarangan, upacara proses pembangunan, material, dimensi, sistem struktur dan konstruksi, fasade bangunan dan lain-lain

\section{Metode Penelitian}

Jenis penelitian adalah penelitian kualitatif. Tempat penelitian dilakukan di Masamba Kabupaten Luwu' Utara, Oktober 2015. Pengumpulan data dilakukan dengan observasi, wawancara, dan dokumentasi eksploratif untuk mencari dokumen-dokumen masa lampau dan menelusuri perubahan bentuk Banua Sulu' Variabel penelitian, terdiri atas: Tata letak yaitu orientasi bangunan terhadap jalan, tata ruang menyangkut jumlah ruang dan jenis ruang, Fasade, Struktur/material struktur, dan ornamen. Teknik analisis data yang digunakan adalah analisis deskriftif kualitatif (Miles \& Huberman 1992), Dengan demikian, tahapan penelitian secara sistematis adalah: Persiapan, pengumpulan data, pemilihan data, penyajian data, dan menganalisis data setiap variabel secara deskriptif, memaknai setiap perubahan yang terjadi dan penarikan kesimpulan. 


\section{Hasil dan Pembahasan}

Kabupaten Luwu Utara adalah salah satu kabupaten di Propinsi Sulawesi Selatan. Ibu kota kabupaten tersebut adalah kota Masamba. terletak pada koordinat 2०30'45"-2 $37^{\prime} 30^{\prime \prime} \mathrm{LS}$ dan

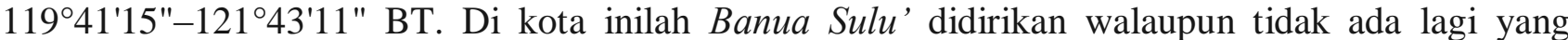
mengetahui secara pasti sejak kapan rumah itu didirikan, namun berdasarkan beberapa orang responden yang diwawancari mereka memperkirakan rumah tradisional ini sudah berdiri sejak ratusan tahun yang lalu.

Satu-satunya bukti fisik yang eksak adalah hasil foto yang dilakukan Albert Grubauer (1911). Foto ini disimpan oleh anak cucu pemilik rumah, dan merupakan bukti outentik bentuk awal dari Banua Sulu'. Oleh sebab itu, untuk menelusuri perubahan bentuk yang terjadi, titik tolak Peneliti adalah dari tahun 1911 berdasarkan foto tersebut sehingga periodasi waktu untuk mengamati fenomena perubahan bentuk rumah tradisioal ini adalah dalam kurun waktu 105 tahun (1911 2015). Untuk memperlihatkan bagaimana bentuk awal rumah tradisional Banua Sulu' dapat diliuhat pada gambar 1 (kiri) di bawah ini. Seiring dengan perubahan waktu, setelah 105 tahun kemudian yaitu tahun 2015 saat penelitian ini berlangsung, maka bentuk rumah Banиa Sulu' sekarang adalah sebagai berikut (Gambar 1 kanan)
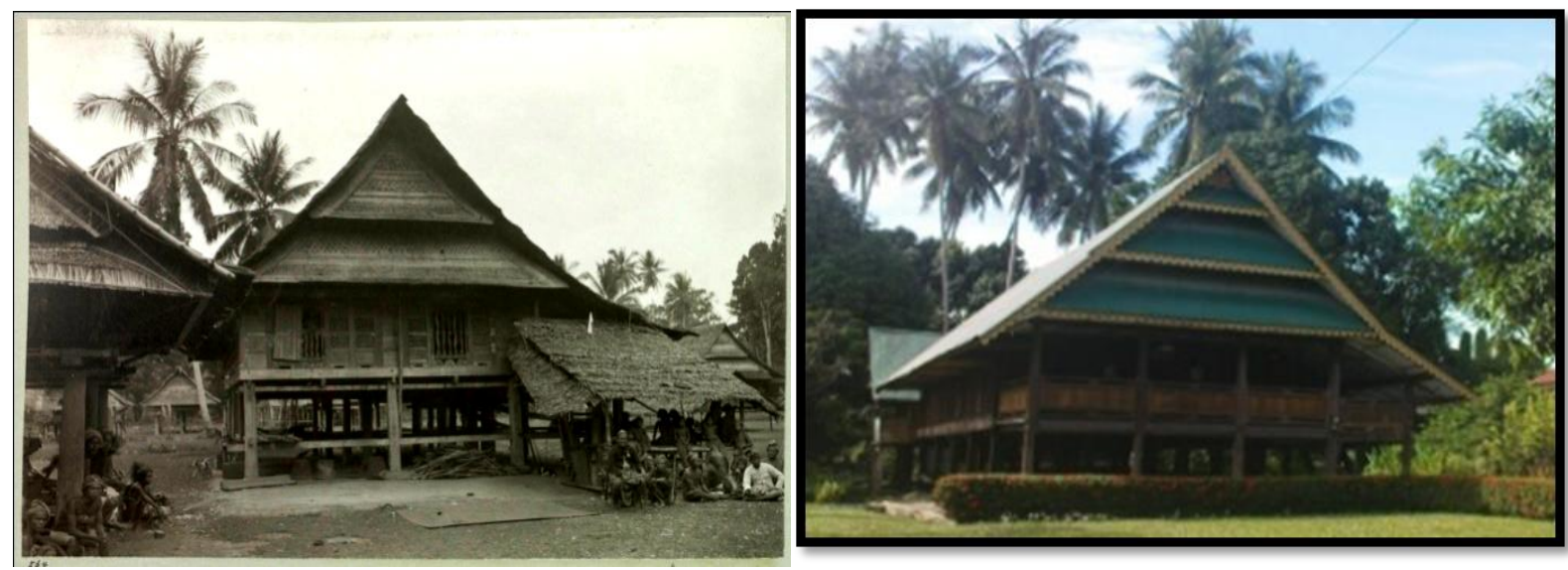

Gambar 1. Kiri: Bentuk awal Banua Sulu’ dan Kanan: Bentuk Banua Sulu' sekarang Sumber: Albert Grubauer, 1911; Foto dokumentasi Peneliti, 2015

Untuk melihat perubahan bentuk secara keseluruhan, dapat disimak berdasarkan analisis situs variabel dengan membandingkan bentuk awal berdasarkan penelusuran data masa lampau, dan keadaan masa kini sebagai berikut:

Tabel 1. Perbandingan Kondisi Awal dan Sekarang

\section{Tata Letak}

\section{Kondisi Awal}

Posisi rumah mengarah ke jalan poros kampung.

Perubahan: orientasi rumah tetap, yang berubah status jalan di depan rumah dari jalan kampung menjadi jalan poros trans sulawesi.

\section{Kondisi Sekarang}

Posisi rumah di pusat kota tetap menghadap pada jalur lintas trans Sulawesi. 


\section{Tata Ruang}
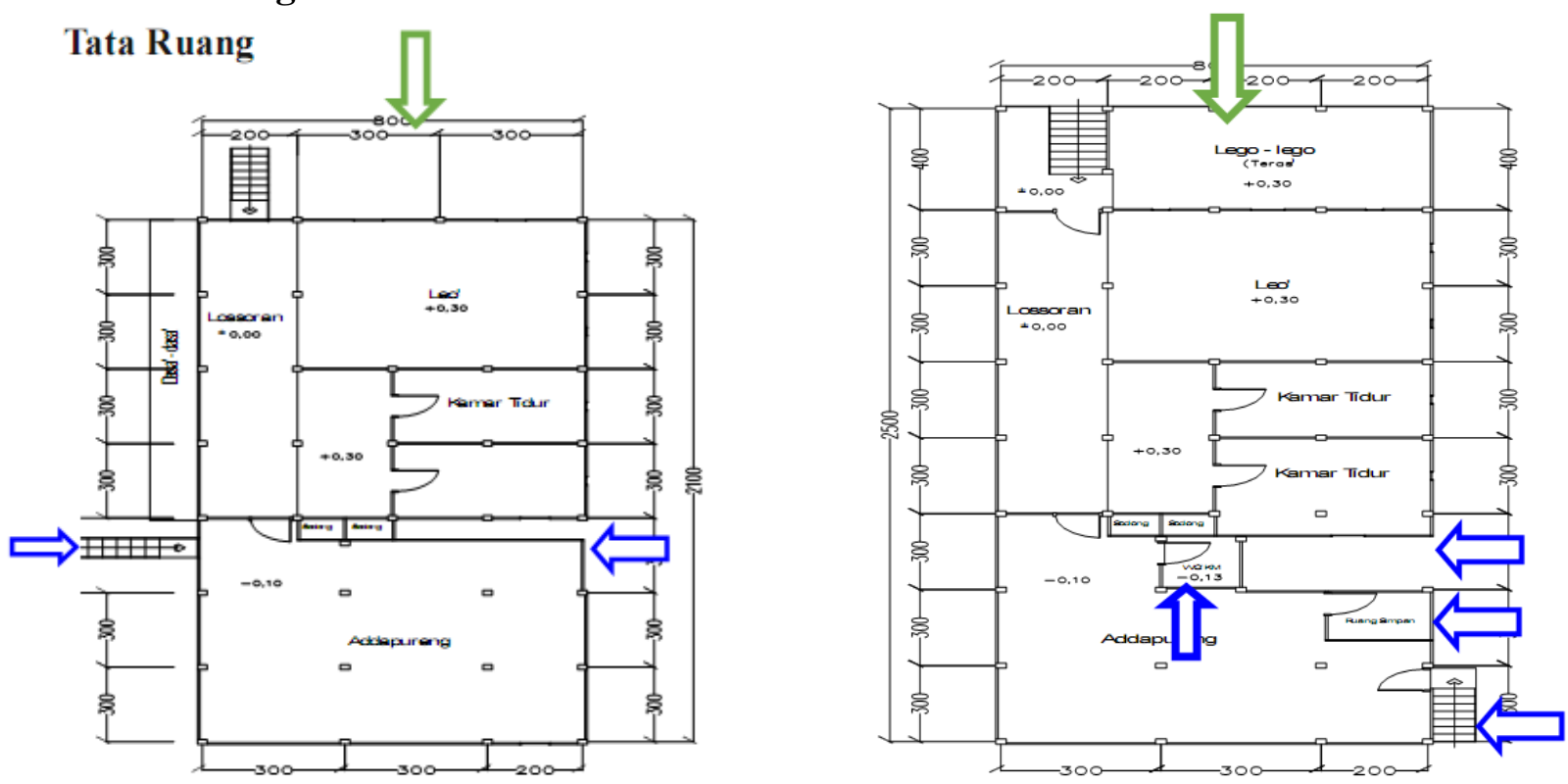

Ruang yang ada :

- Ruang tamu (Leo')

Ruang yang ada :

- Ruang tamu (Leo')

- Tempat penyimpanan

- Jalur masuk (Lossoran)

- Tempat persembun yian (Para)

- Kamar tidur 2 buah

- Ruang Masak / makan (Addapureng)

- Tempat persembunyian (Para)

- Jalur masuk (Lossoran)

- Teras depan (lego-lego)

- Kamar tidur 2 buah

- Ruang penyimpanan alat dapur

- Ruang Masak/makan (Addapureng)

- Kamar mandi / WC

- Tempat penyimpanan

Perubahan: ada penambahan ruang pada teras depan (lego-lego), gudang, dan KM/WC

\section{Fasade}

Bentuk rumah panggung atau rumah kolong yang dibentuk berdasarkan pandangan kosmologi

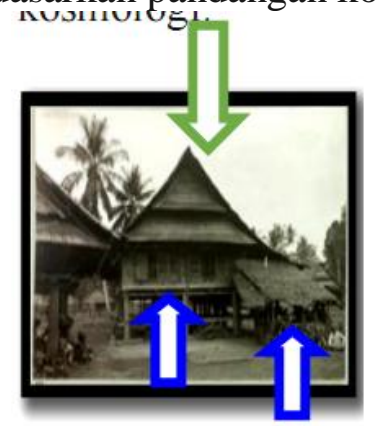

Berbentuk rumah panggung kayu atau rumah kolong

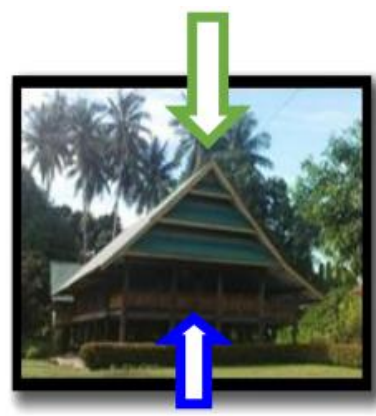

Perubahan: perubahan terjadi pada tangga naik di samping kanan rumah 


\section{Struktur dan Material}

\section{Coppo' (Timpa' Laja)}

Coppo' (Timpa-laja) bersusun 2 susun, dengan ukiran flora.

-Coppo' (Timpa-laja) bersusun 3 susun, menggunakan material seng
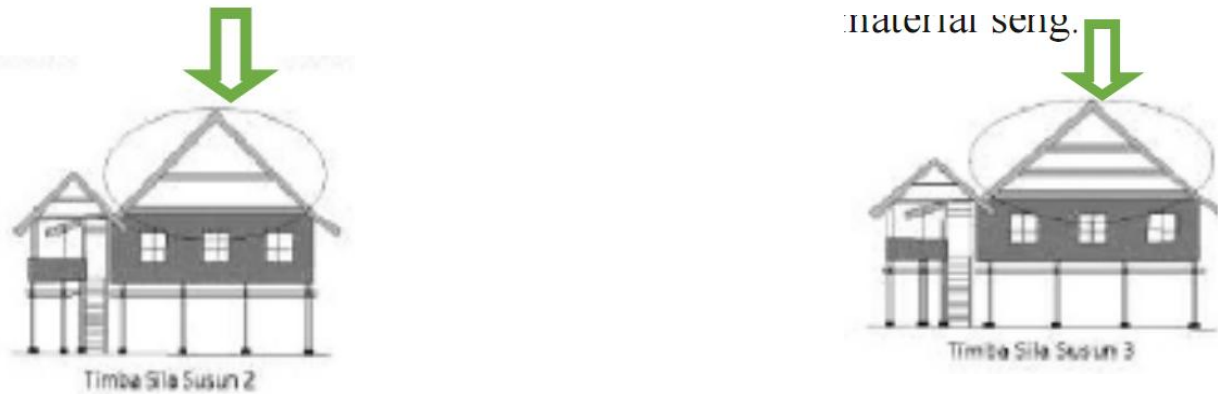

Perubahan: terjadi perubahan pada Coppo’ (timpa laja) sebagai ciri khas rumah bangsawan Bugis Makassar

\section{Material Struktur Atap}

Konstruksi penahan atap menggunakan kayu kalapi.Atap berbentuk Pelana, denga material dari daun sagu (Rumbia

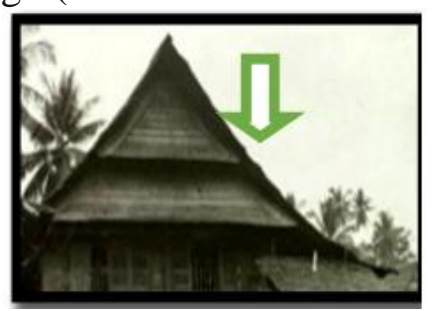

Konstruksi penahan atap menggunakan kayu kalapi. Atap berbentuk Pelana, denga material seng

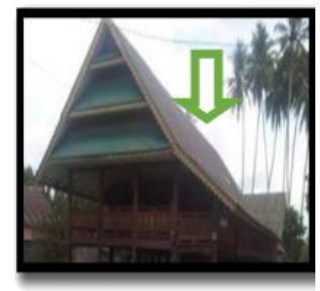

seng

Perubahan: terjadi perubahan dari material atap dari atap daun rumbia menjadi atap

\section{Dinding dan Plafond}

Dinding menggunakan material kayu uru disusun secara horizontal dengan ukiran flora. Tidak memakai plafond

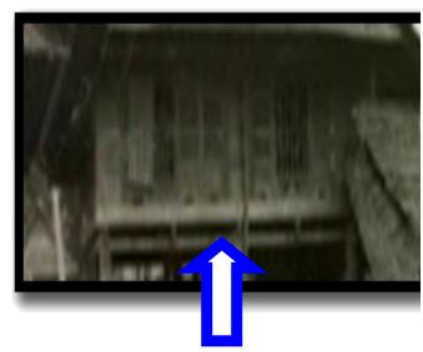

Keseluruhan dinding menggunakan material papan tanpa ukiran flora. Memakai plafond dengan menggunakan asbes dan dicat

Perubahan: Perubahan pada ukiran dinding dan plafon. Dulu tidak memakai plafon sekarang sudah pakai plafon dan dicat (Pengaruh material struktur modern)

\section{Jendela dan Ventilasi}

Bukaan jendela berjumlah 2 dibagian depan, 4 di seblah kanan, dan 2 dibagian kiri rumah. Ventilasi terdapat di samping kiri rumah (sepanjang dinding lossoran)
Bukaan jendela berjumlah 3 dibagian depan, 4 di sebelah kanan, dan 2 dibagian kiri rumah. Bukaan jendela semunya dipasangkan jeruji besi secara vertikal sebagai pengaman. Ventilasi 


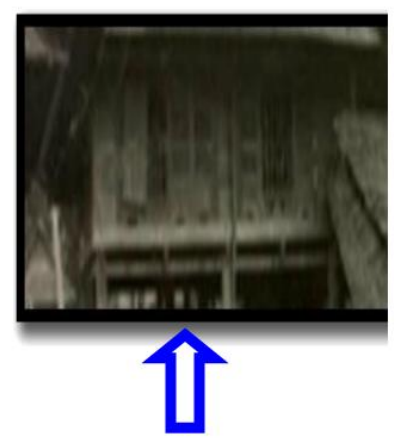

terdapat di samping kiri rumah (sepanjang dinding lossoran).

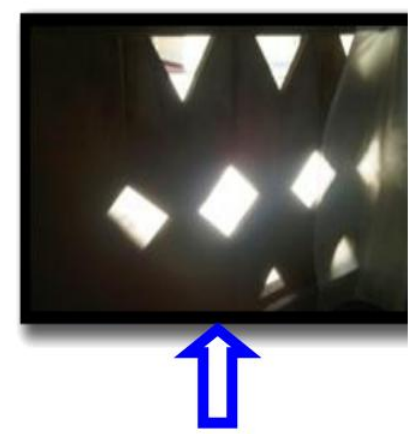

Perubahan: terjadi pada jumlah bukaan jendela di depan rumah, yang awalnya 2 buah menjadi 3 buah.Jeruji pengaan dari besi awalnya tidak ada. Penempatan ventilasi udara masih tetap sama.

\section{Tiang dan Lantai}

Seluruh lantai menggunakan material karurung Ketinggian lanti $\pm 1,5 \mathrm{~m}$ dari permukaan tanah sampai lantai lossoran. Struktur tiang semuanya diSulu', menggunkan material kayu kalapi atau kayu bitti. Tiang-tiang memiliki luas penampang 15 x $15 \mathrm{~cm}$ berjumlah 36 buah.

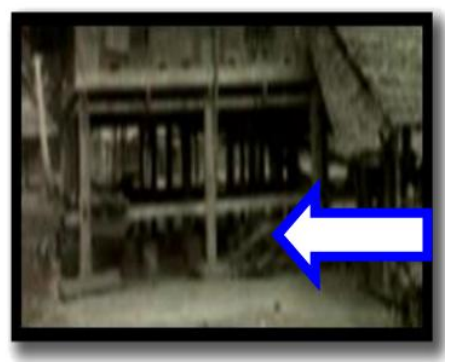

Lantai seluruhnya menggunakan papan. ketinggian lanti $\pm 1,5 \mathrm{~m}$ dari permukaan tanah sampai lantai lossoran. Tiang-tiang menggunakan kayu kalapi atau kayu bitti'. Tiang-tiang memiliki luas penampang $15 \times 15$ cm berjumlah tiang \pm 43 buah.

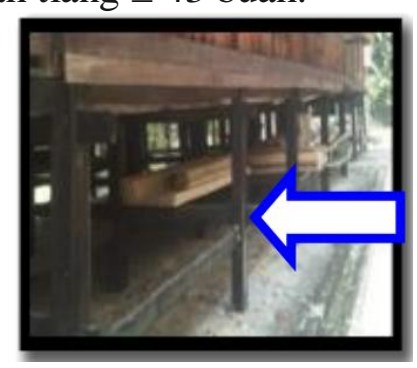

Perubahan: terjadi pada material penutup lantai, dari bahan karurung (batang ijuk/kelapa) menjadi lantai papan. Jumlah tiang bertambah dari 36 menjadi 43 buah, berarti pulah besaran rumah bertambah. Material struktur tiang, dimnsi tiang dan ketinggian dari muka tanah masih tetap sama

\section{Bentuk dan Material Tangga}

Jumlah tangga 2 buah sebagai jalur keluar/masuk rumah 1 di bagian depan dan $1 \mathrm{~d}$ ibagian samping kiri rumah bagian belakang. Jumlah anak tangga 9 baik tangga depan maupun tangga samping. Material tangga menggunakan kayu uru. Atap tangga diberi dari daun rumbia.

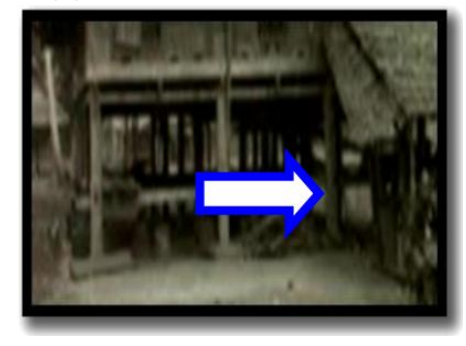

Jumlah tangga 2 buah yang menjadi jalur masuk/keluar rumah yaitu $1 \mathrm{~d}$ bagian depan dan 1 di bagian kanan belakang rumah. Jumlah anak tangga masing-masing 9 anak tangga. Material tangga menggunakan kayu uru. Atap tangga diberi dari bahan seng.

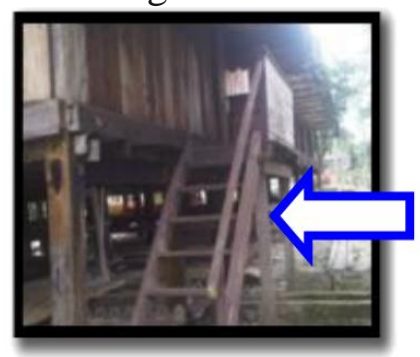

Perubahan: struktur tangga dan material strukturnya tidak mengalami perubahan yang signifikan. Yang berubah hanya material atap tangga dari daun rumbia menjadi atap seng. 


\section{Ornamen}

Ragam hias corak flora berupa bunga parenrengi, digunakan pada corak dinding, jendela, diding, dan penutup bubungan (coppo'). Ragam hias fauna yaitu tanduk kerbau yang dipasang dibagian puncak coppo'. Dinding bagian luar terdapat ukiran-ukiran flora

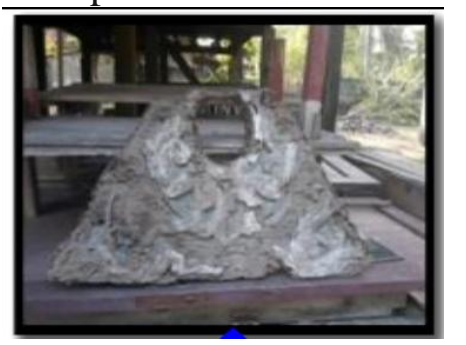

Terdapat giring-giring yang diberi cat kuning, terdapat dibagian tepi coppo' dan seluruh tepi atap. Oramen lampu klasik diguanakan di bagian teras depan rumah. Dinding bagian depan dan dinding bagian ruang Leo terdapat ornamen kaligrafi dan foto yang diberi bingkai.

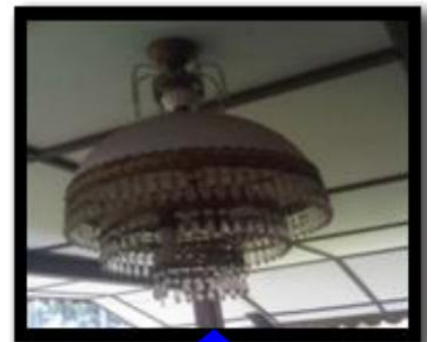

Perubahan Penggunaan ornamen ukiran dengan motif flora dan fauna lebih dominan pada bentuk awal, namun banyak berubah dan lebih menunjukkan nuansa modern pada bentuk akhir

Sumber: Albert Grubauer, 1911; Foto dokumentasi Peneliti, 2015

\section{Pembahasan}

Perubahan bentuk yang terjadi pada rumah tradisional Banua Sulu' di kota Masamba Kabupaten Luwu' Utara, terjadi secara evolusi seiring dengan perjalanan waktu dan perkembangan zaman. Ada dua aspek yang mendorong terjadinya perubahan tersebut. Pertama akibat kemajuan teknologi bahan bangunan atau material struktur pada satu sisi, dan pada sisi yang lain semakin terbatasnya sumber daya alam khususnya bahan-bahan material struktur dari alam yang pada zaman dahulu mudah diambil dan digunakan sebagai pengganti material struktur yang sudah lapuk. Tetapi pada saat ini, hutan semakin jauh sehingga masyarakat semakin sulit untuk mendapatkan bahanbahan tersebut sementara material struktur produk industri tersedia di pasaran dan mudah dibeli. Selain itu, dari segi kualitas produk industri terukur sementara bahan-bahan alam tidak terukur. Sebagai contoh, bahan penutup atap jika pada saat yang lampau memakai atap daun sagu dengan cara pengolahan yang agak rumit sementara bahan ini mudah lapuk dibandingkan dengan bahan penutup atap seng yang mudah dibeli dan lebih awet serta tahan lama dari pada atap daun rumbia, Dengan pertimbangan seperti ini, banyak masyrakat yang memakai atap seng untuk rumah tradisional mereka, tanpa mereka sadari bahwa makna tradisionalnya mulai bergeser.

Aspek yang kedua, akibat perubahan peradaban yang semakin modern. Jika penghuni rumah tradisional Banua Sulu' pada masa lampau belum terpengaruh oleh peradaban modern, sehingga kebutuhan ruang untuk menampung aktivitas mereka masih terbatas dan menerima apa adanya. Namun pada saat ini, generasi berikutnya sudah berada di era modern sehingga membutuhkan penyesuain kebutuhan ruang untuk aktivitas mereka, dan menambah ruang serta memperbaiki bahagian-bahagian struktur rumah mereka sesuai dengan kebutuhannya. Apalagi dengan berubahnya Masamba menjadi ibu kota kabupaten, sehingga rumah ini berada di tengah kota yang semakin maju dan berkembang, dan penghuni rumah Banua Sulu' pun berusaha menyesuaikan diri dan merenovasi rumah tradisional mereka agar tidak kelihatan kumu di tengah-tengah kota modern.

Seperti halnya penelitian yang dilakukan oleh Ronny Sondakh, (2003) dalam Kajian terhadap perubahan struktur konstruksi dan bentuk pada Rumah Tradisional Minahasa Menemukan adanya perkembangan/perubahan pada konstruksi yaitu; Sistem pondasi, sistem balok bantalan, sistem tiang, sistem plafond dan struktur tangga. Dibalik perkembangan/perubahan struktur dan konstruksi tersirat empat makna pokok yang terkait dengan status sosial penghuni sebagai kelompok terdidik, kaya atau 
masyarakat umum. Perubahan terjadi pada tata fisik rumah tinggal disebabkan oleh adanya pola pikir manusia yang berubah. Hasil penelitian tersebut menekankan bahwa perubahan pola pikir, sangat berpengaruh terhadap perubahan yang terjadi pada hunian seseorang, termasuk rumah tradisional Banua Sulu' juga berubah sesuai dengan perubahan pola pikir penghuninya.

\section{Kesimpulan}

Banua Sulu' sebagai rumah tradisional bangsawan di daerah Luwu mengalami banyak perubahan, terutama dalam hal penggunaan material struktur. Hal ini digunakan ketika adanya renovasi, elemen wujud fisik yang paling banyak berubah adalah pada Botting langi atau pada bagian Atap. Selain itu juga terjadi perubahan pada semua elemen bentuk, material, jumlah cappo' atau timpa' laja' sampai pada hilangnya identitas pada bentuk ornamen dinding. Pada bagian badan rumah ( Ale bola ) utamanya lantai dan dinding hampir kesluruhan diganti, serta adanya penambahan ruang yang disebabkan oleh kebutuhan ruang untuk mewadahi aktivitas penghuni, yang telah berubah menjadi masyarakat modern.

\section{Daftar Pustaka}

Albert, Grubauer. 1911. Foto-foto dokumentasi Keluarga.

Altman, Irwin and Werner, Coral M. (1985). Volume 8. Home Environments Human Behavior and Environments. New York and London: Plenum Press.

Depdikbud. (2007). Kamus Besar Bahasa Indonesia Edisi Ketiga. Jakarta: PN Balai Pustaka

Le Corbusier.1923. Toward A New Architecture (Vers Une Architecture, Paris: G. Crès et $\mathrm{Cie}$ ), Frederick Etchells (trans.), New York: Praeger, 1960; John Goodman (trans.) Santa Monica, CA: Getty Publications, 2007.

Lullulangi, Mithen dan Sampebua', Onesimus. (2007). Arsitektur Tradisional Toraja. Makassar : Badan Penerbit UNM.

Machmud. (2006). Architecture Articles. Antariksa. diposting $8 \quad$ Januari 2011. (http://antariksaarticle./, diakses 20 juli 2014)

Mangunwijaya, Y.B. (1992). Wastu Citra. Jakarta: Gramedia.

Miles, M.B and Huberman, A.M. (1992). Analisis Data Kualitatif. Jakarta: UI Press.
Robinson. (1983). Rumah Adat, Tradisi Menre Bola, dan Dapur Orang Bugis Makassar. diposting 2008. Farid. (http://www.rappang.com, diakses 10 Desember 2013).

Ronny Sondakh, Julianus Anthon. (2003). Arsitektur Vernaculer. Proposal Disertasi Pascasarjana UGM Yogyakarta. (online) (repository.unhas.ac.id, diakses 29 September 2014)

Runa, I Wayan. (1993). Arsitektur Vernaculer. Proposal Disertasi Pascasarjana UGM Yogyakarta. (online) (repository.unhas.ac.id, diakses 29 September 2014).

Ruskin, John.1849. The Seven Lamps of Architecture (London: Smith, Elder, and Co.), New York: Dover Publications, 1989.

Said. (2004). Kearifan Lokal Masyarakat Kudus Kulon dalam Tradisi Perawatan Rumah. (http://www.arupadhatu.or.id/artikel/budaya/124 -.html, diakses 07 Juni 2014)

Soeroto, Myrtha. (2003). Sejarang dan Budaya Kebudayaan Toraja. Jakarta : Myrtle Publishing. 